\title{
Pengembangan Parameter Penilaian Keamanan Pelayanan Kesehatan Tradisional Empiris
}

\author{
Development of the Safety Assessment Parameters of Traditional Empirical Health Services
}

Ondri Dwi Sampurno*, Nurhayati, Delima, Lucie Widowati, dan Hadi Siswoyo

Pusat Penelitian dan Pengembangan Sumber Daya dan Pelayanan Kesehatan, Badan Penelitian dan Pengembangan Kesehatan, Kementerian Kesehatan RI, Jln. Percetakan Negara No. 29 Jakarta 10560, Indonesia

*Korespondensi Penulis: ondri19@gmail.com

Submitted: 01-04-2020, Revised: 12-05-2020, Accepted: 18-06-2020

DOI: https://doi.org/10.22435/mpk.v30i2.3055

\begin{abstract}
Abstrak
Dalam rangka perlindungan masyarakat terhadap keamanan pelayanan kesehatan tradisional empiris, dikembangkan parameter penilaian keamanan yang lebih terperinci terhadap aspek penyehat tradisional (hattra), cara perawatan dan sarana. Setiap parameter penilaian keamanan dilengkapi dengan definisi operasional dan diuji validitas serta diuji reliabilitasnya untuk memberikan hasil penilaian keamanan yang obyektif dan hasil penilaian yang konsisten. Pengembangan parameter penilaian keamanan pelayanan kesehatan tradisional empiris dilakukan dengan pendekatan kuantitatif. Parameter keamanan mengacu pada Peraturan Menteri Kesehatan (Permenkes) Nomor 61 Tahun 2016 tentang Pelayanan Kesehatan Tradisional Empiris yang mencakup aspek hattra, cara perawatan, dan sarana. Jumlah item parameter pada masing masing aspek secara berturut-turut adalah 6,27 , dan 16 . Jumlah item parameter pada aspek cara perawatan terbagi menjadi 11 item cara perawatan keterampilan dan 16 item cara perawatan ramuan. Setiap item parameter disertai dengan definisi operasional untuk keseragaman persepsi. Setiap item parameter diberikan skor berdasarkan skala Likert ( $5=$ sangat setuju; $4=$ setuju; $3=$ =netral; 2=tidak setuju; 1 =sangat tidak setuju) untuk evaluasi validitas dan reliabilitas terhadap 36 orang (jumlah untuk memenuhi normalitas) pakar pelayanan kesehatan tradisional. Pakar berasal dari perguruan tinggi dan Asosiasi Penyehat Tradisional. Analisis data menggunakan program SPSS. Analisis validitas menggunakan product moment dari Karl Pearson dan analisis reliabilitas menggunakan Cronbach alpha. Hasil uji validitas menunjukkan bahwa 2 dari 6 item parameter pada aspek hattra valid, 26 item dari 27 item parameter pada aspek cara perawatan valid, dan keseluruhan item dari 16 parameter pada aspek sarana valid. Hasil reliabilitas menunjukkan hasil yang reliabel. Pengembangan parameter penilaian keamanan pelayanan kesehatan tradisional empiris dihasilkan parameter reliabel dan sebagian besar parameter valid. Parameter yang tidak valid sebagian besar dilakukan penyesuaian kalimat tanpa mengubah makna.
\end{abstract}

Kata kunci: parameter; keamanan; pelayanan kesehatan tradisional empiris

\section{Abstract}

In the context of protecting the community against the security of traditional empirical health services, more detailed safety assessment parameters have been developed for the traditional health aspects (hattra), methods of care and facilities. Each safety assessment parameter was equipped with an operational 
definition and tested for validity and tested for reliability to provide objective safety assessment results and consistent assessment results. The development of traditional empirical health service safety assessment parameters was carried out with a quantitative approach. Safety parameters refer to the Minister of Health Regulation (Permenkes) Number 61 of 2016 Concerning Traditional Empirical Health Services which includes aspects of hattra, methods of care and facilities. The number of parameter items in each aspect were 6, 27, and 16. The number of parameter items on the aspect of methods of care was divided into 11 items of methods of skills care and 16 items of methods of herbs care. Each parameter item was accompanied by an operational definition for uniformity of perception. Each parameter item was given a score based on a Likert scale ( $5=$ strongly agree; 4 = agree; $3=$ neutral; 2 = disagree; 1 = strongly disagree) for evaluating the validity and reliability of 36 people (the number to meet normality) health service experts traditional. Experts came from universities and the Traditional Health Association. Data analysis using SPSS program. Validity analysis using Product moment from Karl Pearson and reliability analysis using Cronbach alpha. The results of the validity test showed that 2 of the 6 parameter items in the hattra aspect were valid, 26 items out of the 27 parameter items in the aspect of the treatment method were valid, and all items of 16 parameters in the aspect of the tool were valid. Reliability test showed reliable results. The development of traditional empirical health service safety assessment parameters produced reliable parameters and most of the parameters were valid. Invalid parameters were mostly adjusted by sentence without changing the meaning.

Keywords: parameters; safety; empirical traditional health services

\section{PENDAHULUAN}

Pemanfaatan pelayanan kesehatan tradisional di Indonesia cenderung meningkat. Hasil Riset Kesehatan Dasar (Riskesdas) tahun 2013 menunjukkan bahwa proporsi rumah tangga yang memanfaatkan pelayanan kesehatan tradisional sebesar $30,4 \% .^{1}$ Sementara hasil Riskesdas tahun 2018 menunjukkan bahwa proporsi pemanfaatan pelayanan kesehatan tradisional pada penduduk semua umur sebesar $31,4 \% .^{2}$ Pelayanan kesehatan tradisional 98,5\% diberikan oleh penyehat tradisional (hattra). ${ }^{2}$.

Pelayanan kesehatan tradisional yang diselenggarakan oleh hattra dinamakan sebagai pelayanan kesehatan tradisional empiris. Pelayanan kesehatan tradisional empiris adalah penerapan kesehatan tradisional yang manfaat dan keamanannya terbukti secara empiris. ${ }^{3}$ Bukti empiris terkait keamanan menjadi sangat penting dalam upaya perlindungan masyarakat. Bukti empiris adalah informasi yang membenarkan suatu kepercayaan dalam kebenaran atau kebohongan suatu klaim empiris. ${ }^{4,5}$ Pengertian empiris menurut Kamus Besar Bahasa Indonesia yaitu berdasarkan pengalaman (terutama yang diperoleh dari penemuan, percobaan, dan pengamatan yang telah dilakukan). ${ }^{5}$ Berdasarkan Peraturan Menteri Kesehatan (Permenkes) Nomor 61 Tahun 2016, bukti empiris keamanan pelayanan kesehatan tradisional didasarkan pada hasil penilaian teknis. Penilaian teknis ini dilakukan terhadap metode dan teknik dalam meyelenggarakan pelayanan kesehatan tradisional empiris yang akan diterapkan. ${ }^{3}$

Penilaian teknis terhadap metode dan teknik dalam menyelenggarakan pelayanan kesehatan tradisional menggunakan Form Instrumen Penilaian Teknis Hattra sebagaimana pada Formulir VII Permenkes Nomor 61 Tahun 2016 tentang Pelayanan Kesehatan Tradisional Empiris. ${ }^{3}$ Form instrumen ini dinilai memiliki kelemahan yaitu hasil penilaian cenderung subyektif dan tidak konsisten. Sebagai contoh salah satu item parameter pada Formulir VII Permenkes Nomor 61 Tahun 2016, butir B.1. tertulis "Cara perawatan keterampilan, bila cara perawatan yang digunakan aman dan tidak bertentangan dengan prinsip pelayanan kesehatan 
tradisional empiris maka ditulis "aman". Item ini tidak diuraikan lebih lanjut bagaimana prinsip pelayanan kesehatan tradisional. Parameter dalam form instrumen Permenkes Nomor 61 Tahun 2016 ini belum disertai dengan definisi operasional dan belum dilakukan pengujian validitas dan reliabilitas. Bila parameter penilaian dihasilkan oleh instrumen yang reliabilitas dan validitas hasil ukurnya belum teruji maka hasilnya kurang tepat. ${ }^{6}$

Dalam rangka perlindungan masyarakat terhadap keamanan pelayanan kesehatan tradisional empiris, pada penelitian ini dikembangkan parameter penilaian keamanan lebih terperinci terhadap aspek hattra, cara perawatan dan sarana. Setiap parameter penilaian keamanan dilengkapi dengan definisi operasional dan diuji validitas serta diuji reliabilitasnya untuk dapat memberikan hasil penilaian keamanan yang objektif dan hasil penilaian yang konsisten.

\section{METODE}

Pengembangan parameter penilaian keamanan modalitas pelayanan kesehatan tradisional empiris merupakan bagian dari kegiatan "Penelitian Keamanan Modalitas Pelayanan Kesehatan Tradisional Empiris pada Panti Sehat" di beberapa kabupaten/kota di Jawa dan Bali tahun 2019. Penelitian ini telah mendapat persetujuan etik dari KEPK Badan Litbangkes No. LB.02.01/2/KE.099/2019.

Pendekatan dalam pengembangan ini adalah pendekatan kuantitatif. Parameter penilaian keamanan pelayanan kesehatan tradisional empiris dikembangkan mengacu pada Permenkes Nomor 61 Tahun 2016 tentang Pelayanan Kesehatan Tradisional Empiris yang mencakup aspek hattra, cara perawatan, dan sarana. Jumlah item parameter pada masing-masing aspek secara berturut-turut adalah 6, 27, dan 16. Jumlah item parameter pada aspek cara perawatan terbagi menjadi sebelas item cara perawatan keterampilan dan enam belas item cara perawatan ramuan. Penetapan parameter dilakukan dengan serangkaian pertemuan yang melibatkan pakar bidang pelayanan kesehatan tradisional empiris yang ada di Jakarta. Pakar pelayanan kesehatan tradisional empiris berasal dari Tim Kebijakan Nasional Kesehatan Tradisional, perguruan tinggi, dan Asosiasi Penyehat Tradisional Keterampilan maupun Ramuan. Parameter yang telah ditetapkan bersama pakar dilengkapi definisi operasional untuk keseragaman persepsi. Uraian dalam definisi operasional mengacu pada ketentuan perundang-undangan yang relevan. Setiap parameter diberikan skor berdasarkan skala Likert $(5=$ sangat setuju; $4=$ setuju; $3=$ netral; $2=$ tidak setuju; $1=$ sangat tidak setuju) untuk evaluasi validitas dan reliabilitas. ${ }^{6,7}$ Evaluasi parameter dilakukan terhadap 36 orang (jumlah untuk memenuhi normalitas) pakar pelayanan kesehatan tradisional yang berada di 12 kabupaten/kota. Pakar yang dievaluasi terdiri dari tiga orang per kabupaten/kota sebagai perwakilan dari dinas kesehatan (dinkes) kabupaten/kota, perguruan tinggi dan asosiasi.

Analisis data menggunakan program SPSS. Analisis validitas menggunakan Product moment Karl Pearson dan analisis reliabilitas menggunakan Cronbach's alpha. Untuk item parameter yang tidak valid, dilakukan konfirmasi kepada beberapa pakar terpilih untuk mendapat masukan terkait perubahan item parameter yang tidak valid untuk dilakukan perubahan redaksional atau dihilangkan.

\section{HASIL}

Hasil kesepakatan pakar di bidang kesehatan tradisional, jumlah keseluruhan parameter penilaian keamanan pelayanan kesehatan tradisional empiris pada panti sehat yaitu 49 parameter. Hasil uji validitas dua arah dengan $p=0,05$ menggunakan Product moment dari penilaian 36 orang pakar di bidang pelayanan kesehatan tradisional empiris terhadap parameter penilaian keamanan pelayanan kesehatan tradisional empiris pada aspek hattra, cara perawatan keterampilan, cara perawatan ramuan, dan sarana seperti terlihat pada Tabel 1 - 4 . 
Pada Tabel 1 terlihat parameter penilaian keamanan pelayanan kesehatan tradisional empiris, pada aspek hattra, terdapat 4 dari 6 parameter yang nilai $r$ hitung $<\mathrm{r}$ tabel atau dinilai tidak valid.
Sedangkan pada Tabel 2 terlihat parameter penilaian keamanan pelayanan kesehatan tradisional empiris, pada aspek cara perawatan keterampilan, terdapat 1 dari 11 parameter yang nilai $r$ hitung $<\mathrm{r}$ tabel atau dinilai tidak valid.

Tabel 1. Hasil Analisis Validitas Parameter Penilaian Keamanan Pelayanan Kesehatan Tradisional Empiris pada Aspek Hattra $(n=36$, Dua Arah dengan $p=0,05)$

\begin{tabular}{|c|c|c|c|c|}
\hline No & Parameter & Hasil r hitung & Hasil $r$ tabel & Keterangan \\
\hline 1 & Hattra memiliki sertifikat kompetensi & 0,346020022 & 0,3291 & Valid \\
\hline 2 & Hattra terdaftar sebagai anggota asosiasi & 0,326220081 & 0,3291 & Tidak Valid \\
\hline 3 & Hattra dalam kondisi sehat fisik dan mental & 0,253047434 & 0,3291 & Tidak Valid \\
\hline 4 & Hattra berpenampilan rapi dan bersih & 0,294230588 & 0,3291 & Tidak Valid \\
\hline 5 & $\begin{array}{l}\text { Hattra memberikan konseling terhadap gangguan } \\
\text { kesehatan klien }\end{array}$ & 0,232023621 & 0,3291 & Tidak Valid \\
\hline 6 & $\begin{array}{l}\text { Hattra melakukan pelayanan kesehatan tradisional } \\
\text { empiris terbatas promotif dan preventif }\end{array}$ & 0,383146845 & 0,3291 & Valid \\
\hline
\end{tabular}

Tabel 2. Hasil Analisis Validitas Parameter Penilaian Keamanan Pelayanan Kesehatan Tradisional Empiris pada Aspek Cara Perawatan Keterampilan (n=36, Dua Arah dengan $p=0,05)$

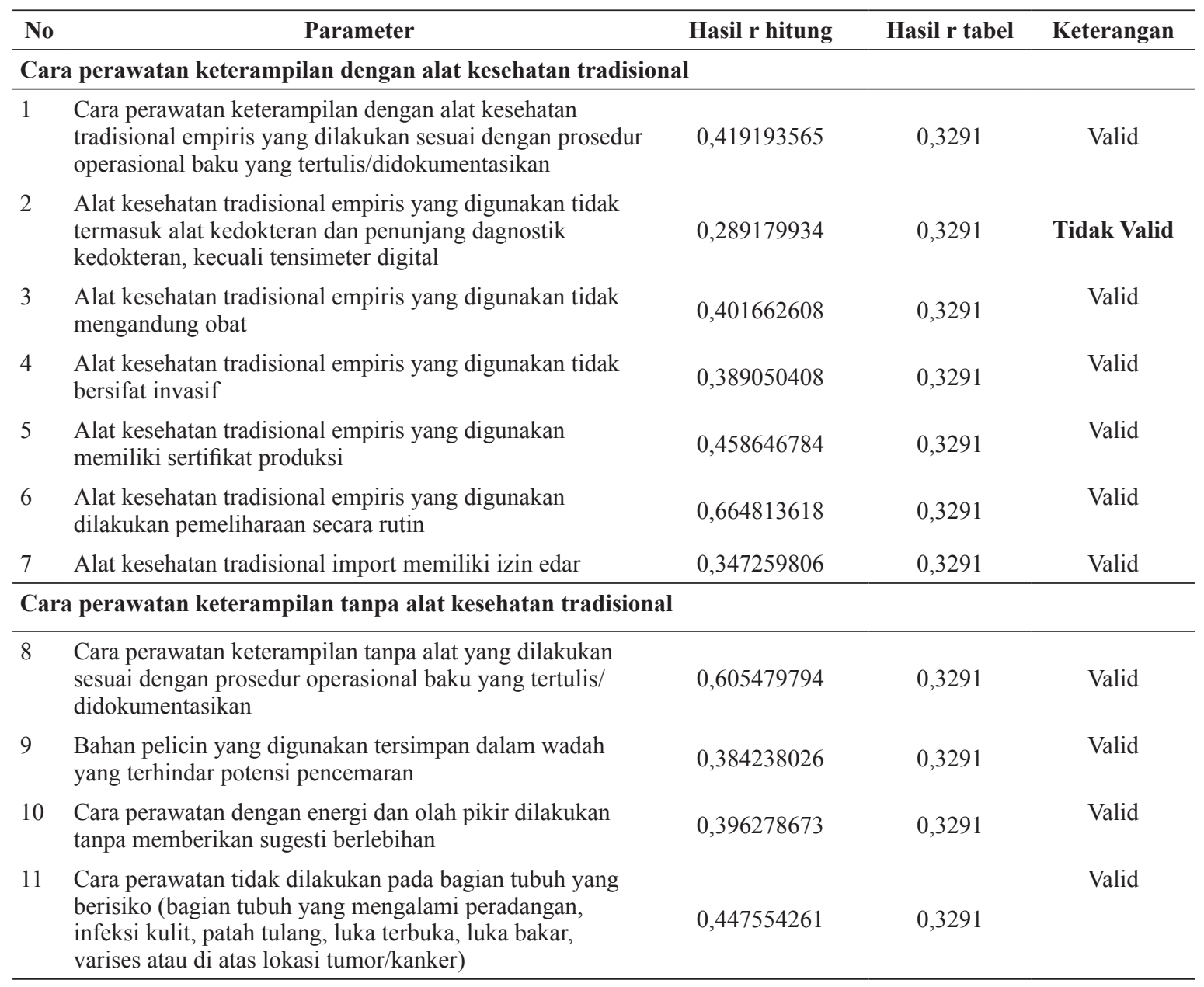


Tabel 3. Hasil Analisis Validitas Parameter Penilaian Keamanan Pelayanan Kesehatan Tradisional Empiris pada Aspek Cara Perawatan Ramuan $(n=36$, Dua Arah dengan $p=0,05)$

\begin{tabular}{|c|c|c|c|c|}
\hline No & Parameter & Hasil r hitung & Hasil $r$ tabel & Keterangan \\
\hline \multicolumn{5}{|c|}{ Cara Perawatan Ramuan Pabrikan } \\
\hline 1 & $\begin{array}{l}\text { Cara perawatan dengan ramuan produksi pabrikan } \\
\text { yang dilakukan sesuai dengan prosedur operasional } \\
\text { baku yang tertulis/didokumentasikan }\end{array}$ & 0,633945915 & 0,3291 & Valid \\
\hline 2 & $\begin{array}{l}\text { Ramuan produksi pabrikan yang digunakan telah } \\
\text { memiliki izin edar dari Badan POM RI }\end{array}$ & 0,457171865 & 0,3291 & Valid \\
\hline 3 & $\begin{array}{l}\text { Bentuk sediaan dari ramuan produksi pabrikan tidak } \\
\text { diubah ke bentuk sedian lain }\end{array}$ & 0,540489573 & 0,3291 & Valid \\
\hline \multicolumn{5}{|c|}{ Cara Perawatan Ramuan Racikan Sendiri } \\
\hline 4 & $\begin{array}{l}\text { Cara perawatan dengan ramuan racikan sendiri yang } \\
\text { dilakukan sesuai dengan prosedur operasional baku } \\
\text { yang tertulis/ didokumentasikan }\end{array}$ & 0,579899283 & 0,3291 & Valid \\
\hline 5 & $\begin{array}{l}\text { Ramuan racikan dibuat sesuai dengan prosedur } \\
\text { operasional baku yang tertulis/didokumentasikan }\end{array}$ & 0,687190286 & 0,3291 & Valid \\
\hline 6 & $\begin{array}{l}\text { Bahan ramuan sendiri mempunyai asal usul yang } \\
\text { jelas }\end{array}$ & 0,557297968 & 0,3291 & Valid \\
\hline 7 & $\begin{array}{l}\text { Ramuan racikan sendiri tidak menggunakan etil } \\
\text { alcohol lebih dari } 1 \%\end{array}$ & 0,256348973 & 0,3291 & Valid \\
\hline 8 & $\begin{array}{l}\text { Ramuan racikan sendiri tidak menggunakan bahan } \\
\text { kimia obat yang merupakan hasil isolasi atau sintetik } \\
\text { berhasiat obat, narkotika dan psikotropika }\end{array}$ & 0,62800079 & 0,3291 & Valid \\
\hline 9 & $\begin{array}{l}\text { Ramuan racikan sendiri tidak menggunakan tanaman } \\
\text { obat yang dilarang sesuai peraturan yang berlaku }\end{array}$ & 0,69209182 & 0,3291 & Valid \\
\hline 10 & $\begin{array}{l}\text { Ramuan racikan sendiri tidak diberikan dalam bentuk } \\
\text { sediaan tetes mata }\end{array}$ & 0,53589453 & 0,3291 & Valid \\
\hline 11 & $\begin{array}{l}\text { Ramuan racikan sendiri tidak diberikan dalam bentuk } \\
\text { sediaan kapsul }\end{array}$ & 0,483825764 & 0,3291 & Valid \\
\hline 12 & $\begin{array}{l}\text { Ramuan racikan sendiri tidak diberikan dalam bentuk } \\
\text { sediaan intra vaginal }\end{array}$ & 0,630096309 & 0,3291 & Valid \\
\hline 13 & $\begin{array}{l}\text { Ramuan racikan sendiri tidak diberikan dalam bentuk } \\
\text { sediaan parenteral }\end{array}$ & 0,630096309 & 0,3291 & Valid \\
\hline 14 & $\begin{array}{l}\text { Ramuan racikan sendiri tidak diberikan dalam bentuk } \\
\text { sediaan suppositoria }\end{array}$ & 0,534062033 & 0,3291 & Valid \\
\hline 15 & $\begin{array}{l}\text { Ramuan racikan sendiri tidak boleh dicampur dengan } \\
\text { ramuan produksi pabrikan }\end{array}$ & 0,418161628 & 0,3291 & Valid \\
\hline 16 & $\begin{array}{l}\text { Label pada kemasan ramuan racikan sendiri hanya } \\
\text { memuat identitas klien, keterangan cara penggunaan/ } \\
\text { pemakaian, dan tidak boleh menambahkan } \\
\text { keterangan khasiat atau keterangan lain }\end{array}$ & 0,595498401 & 0,3291 & Valid \\
\hline
\end{tabular}

Pada Tabel 3 terlihat parameter penilaian keamanan pelayanan kesehatan tradisional empiris, pada aspek perawatan ramuan, keseluruhan parameter yang nilai $r$ hitung $>r$ tabel atau dinilai valid. Sedangkan pada Tabel 4 parameter penilaian keamanan pelayanan kesehatan tradisional empiris, pada aspek sarana, keseluruhan parameter nilai $r$ hitung $>r$ tabel atau dinilai valid.
Hasil analisis reliabilitas menggunakan Cronbach's Alpha dari evaluasi 36 orang pakar di bidang pelayanan kesehatan tradisional empiris terhadap 49 parameter penilaian keamanan modalitas pelayanan kesehatan tradisional empiris pada panti sehat, seperti terlihat pada Tabel 5. Koefisien Cronbach's Alpha berdasarkan parameter yang dinilai dan koefisien Cronbach's Alpha diperoleh nilai 0,96 atau dinilai reliabel. 
Tabel 4. Hasil Analisis Validitas Parameter Penilaian Keamanan Pelayanan Kesehatan Tradisional Empiris pada Aspek Sarana $(\mathrm{n}=36$, Dua Arah dengan $p=0,05)$

\begin{tabular}{|c|c|c|c|c|}
\hline No & Pernyataan & Hasil r hitung & Hasil $r$ tabel & Keterangan \\
\hline 1 & Ruang pelayanan memenuhi persyaratan lingkungan sehat & 0,584839347 & 0,3291 & Valid \\
\hline 2 & Ruang pelayanan memiliki pencahayaan yang cukup, nb & 0,574643599 & 0,3291 & Valid \\
\hline 3 & $\begin{array}{l}\text { Ruang pelayanan bersifat permanen (tidak berpindah-pindah } \\
\text { tempat dan tidak bergabung fisik dengan tempat tinggal atau } \\
\text { unit kerja lainnya) }\end{array}$ & 0,593430291 & 0,3291 & Valid \\
\hline 4 & Pintu ruang pelayanan tidak terkunci & 0,675886432 & 0,3291 & Valid \\
\hline 5 & Ukuran ruang pelayanan minimal 2 x 2,5 m & 0,676695844 & 0,3291 & Valid \\
\hline 6 & $\begin{array}{l}\text { Ruang pelayanan yang lebih dari satu tempat tidur harus ada } \\
\text { sekt dengan tinggi } 25 \mathrm{~cm} \text { dari lantai dan } 50 \mathrm{~cm} \text { dari plafon } \\
\text { (untuk yang menggunakan matras sekat sampai ke lantai }\end{array}$ & 0,700410697 & 0,3291 & Valid \\
\hline 7 & Tersedia ruang tunggu yang terpisah dari ruang pelayanan & 0,811445387 & 0,3291 & Valid \\
\hline 8 & Tersedia toilet/WC yang terpisah dari ruang pelayanan & 0,834035577 & 0,3291 & Valid \\
\hline 9 & Tersedia sarana untuk cuci tangan & 0,842181178 & 0,3291 & Valid \\
\hline 10 & Tersedia dokumen catatan klien & 0,774835534 & 0,3291 & Valid \\
\hline 11 & $\begin{array}{l}\text { Ruang peracikan dan penyimpanan ramuan racikan sendiri } \\
\text { tahan terhadap pengaruh cuaca }\end{array}$ & 0,823963751 & 0,3291 & Valid \\
\hline 12 & $\begin{array}{l}\text { Ruang peracikan dan penyimpanan ramuan racikan sendiri } \\
\text { dapat mencegah masuknya rembesan dan bersarangnya } \\
\text { serangga, binatang pengerat, burung atau binatang lainnya }\end{array}$ & 0,821997147 & 0,3291 & Valid \\
\hline 13 & $\begin{array}{l}\text { Ruang peracikan dan penyimpanan ramuan racikan sendiri } \\
\text { memenuhi higiene dan sanitasi agar tidak tercemar dengan } \\
\text { kuman non patogen atau pencemaran khamer, jamur dan } \\
\text { bakteri }\end{array}$ & 0,755125124 & 0,3291 & Valid \\
\hline 14 & $\begin{array}{l}\text { Ruang peracikan dan penyimpanan ramuan racikan sendiri } \\
\text { memiliki alas yang berjarak dengan tanah atau lantai agar } \\
\text { simplisia tidak bersentuhan dengan tanah atau lantai }\end{array}$ & 0,76765353 & 0,3291 & Valid \\
\hline 15 & $\begin{array}{l}\text { Suhu ruang peracikan dan penyimpanan ramuan racikan } \\
\text { sendiri dikondisikan sesuai dengan simplisia }\end{array}$ & 0,784793809 & 0,3291 & Valid \\
\hline 16 & $\begin{array}{l}\text { Wadah tempat penyimpanan bahan baku racikan diberikan } \\
\text { label dan tertulis nama bahan baku racikan }\end{array}$ & 0,729832782 & 0,3291 & Valid \\
\hline
\end{tabular}

Tabel 5. Hasil Analisis Reliabilitas Parameter Penilaian Keamanan

\begin{tabular}{ccc}
\hline Cronbach's Alpha & $\begin{array}{c}\text { Cronbach's Alpha berdasarkan } \\
\text { parameter yang dinilai }\end{array}$ & Jumlah parameter \\
\hline 0,945749719 & 0,957129686 & 49 \\
\hline
\end{tabular}

\section{PEMBAHASAN}

Penilaian keamanan pelayanan kesehatan tradisional empiris tidak hanya didasarkan pada cara perawatan. Modalitas pelayanan kesehatan tradisional mencakup hattra, cara perawatan, dan sarana. Penilaian keamanan pelayanan kesehatan tradisonal empiris harus dilakukan sebagai suatu modalitas yaitu penilaian secara bersama antara hattra, cara perawatan, dan sarana. Pada pelayanan kesehatan tradisional empiris keterampilan, apabila alat yang digunakan memiliki kualitas baik tetapi digunakan oleh hattra yang tidak memiliki 
dasar teori dan keahlian yang baik, maka akan berpotensi pada keamanan. ${ }^{8,9}$ Demikian pula pada pelayanan kesehatan tradisional empiris ramuan, apabila ramuan dibuat di sarana yang sanitasinya tidak baik dan diberikan oleh hattra yang tidak memahami kerasionalan ramuan, maka juga akan berpotensi risiko keamanan. ${ }^{10-13}$

Pemahaman kerasionalan ramuan, menjadi parameter yang penting. Untuk itu pada aspek hattra, terdapat 2 item parameter yang perlu dimiliki oleh hattra yaitu sertifikat kompetensi dan keanggotaan asosiasi (Tabel 1). Pemerintah bersama Asosiasi Penyehat Tradisional mempunyai kewajiban melakukan pembinaan kepada hattra termasuk dalam hal pemahaman kerasionalan ramuan. Pada pasal 42 Permenkes Nomor 61 Tahun 2016, dinyatakan bahwa pemerintah pusat, pemerintah daerah provinsi dan pemerintah daerah kabupaten/kota melakukan pengawasan secara berjenjang dengan melibatkan institusi terkait, Asosiasi Penyehat Tradisional, dan masyarakat sesuai dengan tugas dan fungsi masing-masing. ${ }^{3}$

Hasil uji validitas dua arah dengan $p=0,05$ menggunakan Product moment dari evaluasi
36 orang pakar di bidang pelayanan kesehatan tradisional empiris terhadap parameter penilaian keamanan modalitas pelayanan kesehatan tradisional empiris pada panti sehat, terdapat 5 parameter dari 49 parameter yang nilai $r$ hitung $<\mathrm{r}$ tabel atau dinilai tidak valid. Dilakukan penyesuaian terhadap parameter yang tidak valid melalui pembahasan dengan pakar. Parameter yang tidak valid dan parameter perubahan sesuai hasil pembahasan dengan pakar seperti terlihat pada Tabel 6.

Uji validitas dilakukan untuk mengetahui kevalidan atau kesesuaian parameter yang digunakan untuk memperoleh data keamanan dari para hattra. Terhadap lima butir pernyataan dari 49 butir pernyataan penilaian keamanan modalitas pelayanan kesehatan tradisional empiris diuji kembali dengan Pearson Product Moment satu arah dengan $p=0,05, \mathrm{n}=36$, diketahui hanya ada dua butir pernyataan yang tidak valid diantaranya satu parameter "hattra memberikan konseling terhadap gangguan kesehatan klien". Parameter ini dengan satu arah maupun dua arah dinyatakan tidak valid. Berdasarkan konfirmasi dengan sebagian pakar

Tabel 6. Perubahan Parameter Penilaian Keamanan Pelayanan Kesehatan Tradisional Empiris yang Tidak Valid Hasil Konfirmasi Pakar

\begin{tabular}{|c|c|c|c|c|c|}
\hline No & Parameter Awal & Hasil $r$ Hitung & $\begin{array}{c}\text { Hasil } \mathbf{r} \\
\text { Tabel }\end{array}$ & Keterangan & Parameter Perubahan \\
\hline 1 & $\begin{array}{l}\text { Hattra terdaftar sebagai anggota } \\
\text { asosiasi }\end{array}$ & 0,326220081 & 0,3291 & Tidak Valid & $\begin{array}{l}\text { Tidak ada perubahan } \\
\text { redaksional }\end{array}$ \\
\hline 2 & $\begin{array}{l}\text { Hattra dalam kondisi sehat fisik } \\
\text { dan mental }\end{array}$ & 0,253047434 & 0,3291 & Tidak Valid & $\begin{array}{l}\text { Hattra dalam kondisi } \\
\text { sehat }\end{array}$ \\
\hline 3 & $\begin{array}{l}\text { Hattra berpenampilan rapi dan } \\
\text { bersih }\end{array}$ & 0,294230588 & 0,3291 & Tidak Valid & $\begin{array}{l}\text { Hattra berperilaku hidup } \\
\text { bersih dan sehat }\end{array}$ \\
\hline 4 & $\begin{array}{l}\text { Hattra memberikan konseling } \\
\text { terhadap gangguan kesehatan } \\
\text { klien }\end{array}$ & 0,232023621 & 0,3291 & Tidak Valid & dihilangkan \\
\hline 5 & $\begin{array}{l}\text { Alat kesehatan tradisional } \\
\text { empiris yang digunakan tidak } \\
\text { termasuk alat kedokteran } \\
\text { dan penunjang dagnostik } \\
\text { kedokteran, kecuali tensimeter } \\
\text { digital }\end{array}$ & 0,289179934 & 0,3291 & Tidak Valid & $\begin{array}{l}\text { Alat kesehatan } \\
\text { tradisional empiris yang } \\
\text { digunakan tidak termasuk } \\
\text { alat kedokteran dan } \\
\text { penunjang dagnostik } \\
\text { kedokteran }\end{array}$ \\
\hline
\end{tabular}


yang sebelumnya terlibat dalam menguji validitas terhadap lima butir pernyataan yang tidak valid, maka butir pernyataan "hattra memberikan konseling terhadap gangguan kesehatan klien" dikeluarkan. Dasar pertimbangan yang diambil yaitu dari kedua hasil analisis dinyatakan tidak valid dan kata "konseling" merupakan istilah yang digunakan oleh tenaga kesehatan. Dalam konseling kesehatan, yang berperan sebagai konselor adalah tenaga kesehatan seperti dokter umum, psikoterapis ataupun perawat dan memiliki ketrampilan sebagai konselor. ${ }^{14}$

Empat parameter lainnya tetap dimasukkan sebagai parameter penilaian dengan koreksi kalimat untuk mempertajam keterkaitan dengan aspek keamanan, sesuai masukan dari para pakar. Hal tersebut dilakukan dengan memperhatikan perbedaan antara $r$ hitung dengan $r$ tabel $<25 \%$. Terkecuali pada parameter "hattra terdaftar sebagai anggota asosiasi" tidak mengalami perubahan redaksional. Hal ini dinilai sudah cukup jelas dan merupakan parameter yang dinilai penting untuk menekankan peran asosiasi dalam mendukung pemerintah dalam aspek pembinaan hattra terutama pada aspek keamanan.

Koefisien Cronbach's Alpha berdasarkan parameter yang dinilai dan koefisien Cronbach's Alpha diperoleh nilai $>0,6$. Dengan demikian parameter penilaian keamanan sebagai modalitas pelayanan kesehatan tradisional empiris menunjukkan reliabilitas yang tinggi. Cronbach's Alpha adalah ukuran konsistensi internal, yaitu seberapa dekat terkait satu set parameter sebagai kelompok. Ini sebagai ukuran skala reliabilitas. Aturan umum bahwa realibilitas baik bila $>0,6$ dan semakin tinggi reliabilitas maka semakin baik atau semakin tinggi konsistensi internal. ${ }^{15,16,17}$

Setiap item parameter dilengkapi dengan definisi operasional sebagai batasan dan kesegaragam persepsi. Uraian dalam definisi operasional mengacu pada ketentuan perundangundangan yang berlaku. Mengingat ruang penulisan terbatas, pada pembahasan ini diuraikan tiga item paramater. "Hattra memiliki sertifikat kompetensi" (Tabel 1) adalah hattra pernah mengikuti pelatihan atau kursus yang dibuktikan dengan sertifikat kompetensi yang dikeluarkan oleh Lembaga Sertifikasi Kompetensi (LSK)/ Lembaga Kursus Pelatihan (LKP)/Lembaga Pendidikan Keterampilan (LPK) yang menjadi mitra dan diakui oleh Instansi Pembinaan Kursus dan Pelatihan Kementerian Pendidikan dan Kebudayaan. Definisi operasional ini mengacu pada Permenkes Nomor 61 Tahun 2016 pasal 3 butir $3 .^{3}$

"Alat kesehatan tradisional empiris yang digunakan memiliki sertifikat produksi" (Tabel 2) adalah sertifikat yang dikeluarkan oleh produsen terkait spesifikasi alat tersebut. Definisi operasional ini mengacu pada Permenkes Nomor 61 Tahun 2016 dan Permenkes Nomor 62 Tahun 2017 Tentang Izin Edar Alat Kesehatan., ${ }^{318}$ Dalam hal alat kesehatan tradisional yang dibuat sendiri ataupun modifikasi, maka parameter ini diabaikan. Parameter penilaian keamanan dari alat yang dibuat sendiri atau modifikasi terbatas pada sifat invasif.

"Suhu ruang peracikan dan penyimpanan ramuan racikan sendiri dikondisikan sesuai dengan simplisia" (Tabel 4) adalah ruang peracikan dan ruang penyimpanan ramuan racikan tersendiri untuk mengurangi risiko kontaminasi, pembentukan kapang atau fermentasi, dianjurkan agar menyimpannya di ruangan atau di dalam wadah yang diventilasi dengan baik. Hal ini mengacu pada Permenkes Nomor 61 Tahun 2016 dan Petunjuk Penerapan Cara Pembuatan Obat Tradisional yang Baik. ${ }^{3,19,20}$

Nilai keamanan pelayanan kesehatan tradisional empiris akan didapatkan dari parameter keamanan yang valid dan reliabel. Setiap item parameter tersebut akan dinilai berdasarkan kesesuaian terhadap setiap item pernyataan, dan dinilai berdasarkan besaran konstribusi hattra, cara perawatan dan sarana terhadap faktor keamanan. Nilai keamanan ini selanjutnya sebagai dasar perhitungan nilai batas atau cut off "aman". Instrumen ini akan 
sangat bermanfaat bagi petugas lapangan dinas kesehatan kabupaten/kota untuk melakukan penapisan keamanan pelayanan kesehatan tradisional yang banyak di masyarakat. Hasil penapisan dapat dimanfaatkan lebih lanjut untuk pembinaan ataupun rekomendasi untuk salah satu persyaratan perolehan Surat Terdaftar Penyehat Tradisional (STPT).

\section{KESIMPULAN}

Pengembangan parameter penilaian keamanan pelayanan kesehatan tradisional empiris dihasilkan parameter reliabel dan sebagian besar parameter valid. Parameter yang tidak valid sebagian besar dilakukan penyesuaian kalimat tanpa mengubah makna. Setiap parameter disertai dengan definisi operasional mengacu ketentuan perundang-undangan yang relevan.

\section{SARAN}

Hattra dengan cara perawatan keterampilan dengan alat kesehatan tradisional cenderung menggunakan alat kesehatan tradisional yang dibuat sendiri ataupun dimodifikasi dari alat yang ada oleh hattra. Ketentuan yang ada masih terbatas mengatur alat kesehatan yang diproduksi oleh industri. Untuk itu, perlu ada pengaturan mengenai spesifikasi alat kesehatan tradisional tersebut, terutama dikaitkan dengan faktor keamanan.

\section{UCAPAN TERIMA KASIH}

Tim penulis menyampaikan terima kasih Pusat Penelitian dan Pengembangan Sumber Daya dan Pelayanan Kesehatan, Badan Penelitian dan Pengembangan Kesehatan atas dukungan adminstrasi dan pembiayaan sehingga penelitian ini berjalan dengan baik. Terima kasih juga tim penulis sampaikan kepada para pakar yang berkontribusi memberikan masukan dalam pengembangan parameter penilaian keamanan pelayanan kesehatan tradisional empiris.

\section{DAFTAR PUSTAKA}

1. Badan Penelitian dan Pengembangan Kesehatan. Laporan Riskesdas Tahun 2013. Jakarta : Badan Penelitian dan Pengembangan Kesehatan ; 2014.

2. Badan Penelitian dan Pengembangan Kesehatan. Laporan Riskesdas tahun 2018. Jakarta : Badan Penelitian dan Pengembangan Kesehatan ; 2019.

3. Kementerian Kesehatan RI. Peraturan Menteri Kesehatan nomor 61 tahun 2016 tentang Pelayanan Kesehatan Tradisional Empiris. Jakarta : Kementerian Kesehatan RI; 2016.

4. Bukti Empiris, https://id.wikipedia.org/wiki/ Bukti_empiris diakses tanggal 18 Januari 2019.

5. Empiris, https://kbbi.web.id/empiris diakses tanggal 18 Januari 2019

6. Saifuddin A. Reliabilitas dan Validitas Edisi IV. Yogyakarta : Pustaka Pelajar; 2012.

7. Sullivan GM, Artino Jr AR. Analyzing and Interpreting Data From Likert-Type Scale. Journal of Graduate Medical Education. 2013;(5)9:541542, https://doi.org/10.4300/JGME-5-4-18.

8. World Health Orgaization. Global Report on Traditional and Complementary Medicine. Luxembourg : World Health Orgaization; 2019.

9. Shofiah S, Nada S. Obat Tradisional: Antara Khasiat dan Efek Sampingnya. Majalah Farmasetika. 2017;(2)5:1-4

10. Badan Pengawas Obat dan Makanan RI . Petunjuk Penerapan Cara Pembuatan Obat Tradisional yang Baik untuk Usaha di Bidang Obat Tradisional, Edisi 2015, Jilid I. Jakarta : Badan Pengawas Obat dan Makanan RI; 2015.

11. Badan Pengawas Obat dan Makanan RI. Pedoman Rasionalisasi Obat Tradisional, Volume 1. Jakarta : Badan Pengawas Obat dan Makanan RI; 2014.

12. Handayani L, Suharmiati. Cara Benar Meracik Obat Tradisional. Jakarta : AgroMedia; 2005.

13. Swandari P, et al. Pola Penggunaan Obat Bahan Alam Sebagai Terapi Komplementer pada Pasien Hipertensi di Puskesmas. Jurnal Sains dan Kesehatan. 2017;(1)7: 367-376, tersedia pada https://doi.org/10.25026/jsk.v1i7.56 
14. Asriyanti R. Konseling dalam Bidang Kesehatan. Orasi. $2015 ;(6) 1: 1-13$.

15. The Open University, Cronbach's alpha SPSS tutorial, from http://www.open.ac.uk/ socialsciences/spsstutorial/files/tutorials/ cronbachs-alpha.pdf, diakses tanggal 19 Desember 2019

16. Introduction to SAS. UCLA: Statistical Consulting Group. Tersedia pada https://stats.idre.ucla.edu/ sas/modules/sas-learning-moduleintroduction-tothe-features-of-sas/ diakses tanggal 19 Desember 2019

17. Salim OC, et al. Validitas dan Reliabilitas World Health Organization Quality of Life-BREF Untuk Mengukur Kualitas Hidup Lanjut Usia, Uviversa Medicina. 2016; (26)1; 27-38. Tersedia pada https://doi.org/10.18051/UnivMed.2007.v26.2738
18. Kementerian Kesehatan RI. Peraturan Menteri Kesehatan Nomor 62 tahun 2017 tentang Izin Edar alat Kesehatan. Jakarta : Kementerian Kesehatan RI; 2017.

19. Badan Pengawas Obat dan Makanan RI. Petunjuk Penerapan Cara Pembuatan Obat Tradisional yang Baik Untuk Usaha di Bidang Obat Tradisional, Edisi 2015, Jilid II. Jakarta : Badan Pengawas Obat dan Makanan RI; 2015.

20. Badan Pengawas Obat dan Makanan RI. Petunjuk Penerapan Cara Pembuatan Obat Tradisional Yang Baik Untuk Usaha Di Bidang Obat Tradisional, Edisi 2015, Jilid III. Jakarta : Badan Pengawas Obat dan Makanan RI; 2015. 